\title{
Glossaire des termes techniques en français, rédigé à partir du Vocabulaire Français du CIETA (1973)
}

\section{(2) OpenEdition}

Journals

Édition électronique

URL : https://journals.openedition.org/tc/346

DOI : $10.4000 /$ tc.346

ISSN : 1952-420X

Éditeur

Éditions de l'EHESS

Édition imprimée

Date de publication : 1 janvier 2000

ISSN : 0248-6016

Référence électronique

"Glossaire des termes techniques en français, rédigé à partir du Vocabulaire Français du CIETA

(1973) », Techniques \& Culture [En ligne], 34 | 2000, mis en ligne le 26 octobre 2005, consulté le 29

septembre 2022. URL : http://journals.openedition.org/tc/346 ; DOI : https://doi.org/10.4000/tc.346

Ce document a été généré automatiquement le 29 septembre 2022.

Tous droits réservés 
Glossaire des termes techniques en français, rédigé à partir du Vocabulaire Français du CIETA (1973) 